\title{
The Effectiveness of Group Counseling to Improve Students' Social Skill in Telkom University Bandung
}

\author{
${ }^{1}$ MUTIA QANA'A, ${ }^{2}$ ENDAH NAWANGSIH \\ ${ }^{1}$ Fakultas IImu Terapan, Telkom University, Jl. Telekomunikasi No.1, Dayeuhkolot Bandung, \\ ${ }^{2}$ Fakultas Psikologi, Universitas Islam Bandung, Jl. Tamansari No.1 Bandung, \\ email: 1mutia@tass.telkomuniversity.ac.id, 2nawangsihendah@yahoo.com
}

\begin{abstract}
This study aims to see the effectiveness of group counseling in improving student social skills. Many students complain about social problems such as the difficulty to get along with and be accepted in the campus which is a new environment for them. These problems will impact on students' psychological conditions such as the decline of learning motivation, inferior feeling and even intention to resign. One of the campuses that were examined in this study was Telkom University Campus. Based on student unit data, the rate of student resign is increasing which it is a challenge for the institution. One of ways to handle student problems on psychosocial aspects such as unsociable and having no social skill is by establishing and consulting to group counseling. The group can be one of media in dealing with adolescent social problems because the task of adolescents' development is to have peer groups. This research used Quasi-Experimental method with One-Group Pretest-Posttest Design, and the research subject was Telkom University student. Based on the Wilcoxon Statistics test, it showed that the $Z$ value is -2.023 with a significance level of $a=0.05$, which means the group counseling improved social skills of Telkom University students.
\end{abstract}

Keywords: Effectiveness, Group Counseling, Social Skills.

\section{Introduction}

University as the continuation of secondary education aims to educate its students to become society members with academic and professional skills that can implement, develop and create knowledge, technology, and art (Laws 2 of 1989, Section 16, Article 1).

Telkom University is one of well-known private universities in Bandung in ICT field. It has vision to be a World Class University based on the development of technologybased knowledge that becomes a challenge for the institution itself. Telkom University must be able to manage human resources of lecturers and students well.

The students of Telkom University come from various regions in Indonesia. Every year student body consists of 6.000-7.000 students with the composition of $40 \%$ from Makasar, 20\% from Padang and Riau, 20\% from Medan, $10 \%$ from Kalimantan, and the rest of $10 \%$ from Java Island (Source: Student Unit of Tel-U, 2015).
Student interaction from various difference cultures has a potential to create problems, especially in communication. Communication will influence social relationship and student adaptation. Based on data from Telkom student units i.e counseling data, students complaints, and resignation data, every year there are students who have problems that need to be studied further.

This study used data from students of Informatic Management study program. In academic year of 2013 - 2014, total of students who resign were 39 out of 120 students with problems. In detail, there were 8 students having economic problem, 11 students have motivation problem, and 20 students have adaptation problem. From this data, adaptation problems become the main cause which make students resign.

In general, there are some causative factors which make students have difficulties in adapting with new environment, one of which is communicating with other students from different cultures. For example, students from Medan have habits of speaking in high

Received: April 11, 2018, Revision: July 30, 2018, Accepted: December 6, 2018

Print ISSN: 0215-8175; Online ISSN: 2303-2499. DOI: http://dx.doi.org/10.29313/mimbar.v34i2.3675.389-396

Accredited B based on the decree No.040/P/2014, valid on February, 18, 2014 until February, 18, 2019. Indexed by DOAJ, Sinta, IPI 
pitched voices, while those from Java have low voices. In time when they interact, there is a probability of misunderstanding due to that different tone in delivering messages which can be considered as rude for one party. Other example is the lack of tolerance and empathy to help one another in academic activities of study group or doing homework.

Other specific problems, for instance, are some students who have GPA decrease due to the feeling of unaccepted or unnoticed by their classmates, rarely invited to the discussion because of being passive, and refused to be in the group. Those things make students feel uncomfortable and decrease their motivation in learning, have low-class attendance, have difficulties to concentrate, and can not do their tasks well.

There are problems that mostly students have, such as inability to express emotion well thus feel depressed, get tense when interacting with other which make them difficult to socialize, unable to handle interpersonal conflict, and tend to avoid social environment. Being individual, they experience some irrational thoughts such as the feeling that their friends avoid them, having no self-confidence, and often feeling insecure. All those cases will become barriers to their psychosocial development.

The symptoms described above showed that they have difficulty in social interaction since they have no social skill. Individuals with low social skill will tend to be rejected by their friends because they cannot socialize well (Gimpel \& Merrell: 1998).

In general, social skill can be categorized into two groups, namely skilled social individual and unskilled social individual. The skilled social individual usually can solve various problems in his/her social life. They have no difficulties to interact with new friends, communicate effectively with others, involve in interactive discussion or talk with people, and enable to end discussion or talk without hurting anyone. Otherwise, the unskilled social individual find it hard to begin a conversation, especially with people they do not know well yet. They usually feel awkward and cannot join in exciting conversation (Ramdhani, 1994).

According to Laursen $(2005,138)$, one of the ways to improve social skill is through group counseling. Group counseling is a counseling consisting of $4-8$ counselings by meeting 1-2 counselors. Some problems can be discussed in group counseling process, such as how to get skill in developing relationship and communication, self-esteem development, and problem-solving skills (Pauline Harrison, 2002 in Kurnanto).

The basic factor of group counseling is that they can help to solve problem faced by individual. Group counseling focuses on effort to make change by paying attention to daily development and adjustment, such as behavior modification, development of interpersonal skill, value, attitude or career decision making. (Gibson and Mitchell, 1981 in Latipun; 2008). Wiener states that group interaction has positive influences on individual life because group can function as therapeutic media.

In group, a social microcosm will occurs in the form of integration between group members, members with therapist, and members with other members as a whole. All processes occur in group can help to build new and better self-understanding (Agustina, 2017).

In group counseling, there are some therapeutic factors which have crucial contribution to help individual to overcome his/her problem (Yalom : 1985). Therapeutic factors aforementioned is relationship of healing and helping between counselor and client in solving client's problems by involving psychology functions such as empathy, attachment, warmth and intimacy. The therapeutic factors referring to Yalom theory includes installation of hope, universality, imparting of information, altruism, the corrective recapitulation of the primary family group, development of socializing technique, imitative behavior, interpersonal learning, group cohesiveness, catharsis, and existential factors.

These therapeutic factors in group counseling will psychologically influence one's social skill development. Some studies showed that group use in various functions of academic and counseling is beneficial. Group counseling can give individuals various group experiences that help them to learn how to play roles effectively, develop tolerance to stress and anxiety, find satisfaction in working and living together with others, and improve social skill (Corey \& Corey, 2008).

Social skill based on Stephen theory (Cartledge \& Milburn, 1993: 15) consists of four aspects, namely: (1) Environmental Behavior is the form of behaviour which shows 
social behaviour of individuals in recognizing and treating environment; (2) Interpersonal Behavior is form of behaviour which shows social behaviour of individuals in recognizing and making relationship with other individuals (friends or teacher); (3) Self-Related Behavior is form of behaviour which shows social behaviour of individual to himself/ herself; and (4) Task Related Behavior is a form of behaviour or individual response to some academic tasks.

Stephens' theory (Catrledge \& Milburn, 1993, 14) explains that social skill involves two dimensions, i.e. cognitive and affective as crucial determinants to social function. There are some skills that must be mastered by an individual relating to these two dimensions. First is cognitive dimension which functions to control his/her emotion and behaviour to be in harmony with environment that includes social perception and cognitive restructurization. Second is social perception as a skill of individual to accept and measure the situation occurs along with appropriate behaviour determination with response to other's behaviour, problem-solving, and self-control skill. Meanwhile, cognitive restructurization is a skill of individual to rebuild self-confidence system from irrational to rational through understandings of negative thinking that often occurs, and also to face helpless feeling by bringing out more self-positive understanding and more realistic to view themselves.

Meanwhile, affective dimension (feeling and emotion) is difficult to be measured, but visible behaviour pattern as form of feeling expression tends to show the feeling and emotion of individual. The skills should be achieved in social skill training related to affective dimension are self belonging feeling (sense of belonging over one self), understanding of individual characteristics, self and other emotional understanding, care to individual and others either verbal and non verbal (Kratwohl, Bloom \& Masim in Cartledge \& Milburn, 1993, 19).

In this study, the approach implemented was cognitive dimension by changing the perception or point of view of the counselee to his/her environment. It aims to make all the processes in group counseling can help students building their new self-understanding with new better perception. The students can understand themselves and others, be more sensitive to recognize their own and other emotions, learn social interaction in group, and create positive atmosphere among group members in order to learn how to solve problems with the help of other group members. Finally, all social skills aspects previously described will increase and the group counseling will become an effective media to solve problems.

Based on the explanation above, the hypothesis of this study would be: group counseling is effective to improve students' social skill.

\section{Research Method}

This study aimed to find out whether group counseling is effective to improve students' social skill. The research design implemented was research design to see the effectiveness of treatment to the research problem. Thus, the research method designed that was implemented was quasiexperimental.

Quasi experimental is one of experimental design types with the process that not all extraneous variables can be controlled strictly, which means the control to variables are not strict and limited by some considerations (Christensen, 1988).

This study used one-group pretestposttest design. According to Christensen (2001) in Seniati et al (2005), one-group pretest-posttest design is also called beforeafter design. In this design, at the beginning of study it took a measurement of students' social skill before delivering the treatment; then after treatment, the measurement was taken again with the same measurement tool. Through the use of this design, it can be seen whether there was a change or not as the result of treatment delivered by comparing pre-treatment score with post-treatment score.

The instrument used in this study was questionnaire of social skill modified by the researcher based on social skill aspects from Cartledge \& Milbun (1993, 15). Sample of study used purposive sampling, which were students of Telkom University having specific characteristics recommended by their counseling lecturer related to social interaction problems and low social skill based on the result of questionnaire, interview, and observation.

The procedures consisted of initial measurement through questionnaire and intervention delivery through group counseling to students of low social skill. The second measurement was taken from one until two 
weeks after group counseling delivered. Technically, the interval was determined based on consideration that length of time was enough for students to understand the improvement they have already had which allow them to get treatment in intervention process. In this study, the procedure consisted of group counseling delivery to students with low social skill. The group were five students having low social skill based on total score of questionnaire delivered in pre test.

Group counseling was delivered in seven meetings together with one additional individual counseling to monitor the changes on students' social skill aspects. In the initial step, the roles of group counselor have major influence on the steps of counseling activities. Prayitno (1995) states that the roles of counselor in initial counseling is someone who can help the counselees to achieve their aims, trigger and reinforce member participation, evoke the interest and needs of members, build togetherness attitude and group spirit. Relating to all those roles, thus a counselor as counseling practitioner should equip themselves with group counseling competency (Kurnanto, (2013: 7).

The details of group counseling procedures are as follows: the first meeting was introduction, counseling contract, and building group atmosphere in order to make each group member knew each other. In this session, a personification picture game was held to give participants positive feedback to each other. Then the counselor asked each members to express their hopes and aims to join group counseling and gave motivation to the participants to be ready to join the counseling. Therapeutic factors that wished to achieve were installation of hope and information delivery about group counseling.

In the second meeting, the participants were asked to write down 20 interesting things about themselves, presented it in front of other group members and then gave and receive positive feedback. Counselor gave information about task of adolescent social development, then each members shared their experiences related to their barriers in making social relationship. As for fellow members, they listened and gave positive encouragement. The therapeutic factors that wished to achieve were information delivery, altruism, and universality.

In the third meeting, participants were asked to solve problems related to social interaction by doing role-playing. From the problems given, each group members shared what they felt and found during role-playing. They were also asked to identify social behaviour that is acceptable and unacceptable along with the consequences.

In the fourth meeting, the participants were trained using role-playing. They were asked to write a social situation that was difficult to be faced, then asked to act so. After that, they tried to identify the behaviour that should be given and found out the most comfortable situation in performing the interaction.

In the fifth meeting, the participants were asked to express their point of view about environment and negative thoughts that crossed their mind when they do social interaction. The counselor then tried to dig each members' beliefs step by step to find a way to give them another alternative point of view to see social environment. After that, each group members told their point of view and gave feedback in order to have new perceptions. In this meeting, the counselor asked the participants to make a simple action plan to solve their problems.

In the sixth meeting, the participants were asked to present their action plan and each group members gave their suggestions and revisions on action plan designed. In the seventh meeting, the participants and counselor evaluated and identified all problems that had been solved.

\section{Research Result}

The result and discussion of this study will be explained descriptively for each subject studies. Based on processed data, the result of measurement for all group members are presented in Table 1.

Table 1

Data of Social Skill Result Data

\begin{tabular}{|c|c|c|c|c|c|c|c|c|c|c|}
\hline \multirow{3}{*}{$\mathbf{S}$} & \multicolumn{10}{|c|}{ SOCIAL SKILL ASPECTS } \\
\hline & \multicolumn{2}{|c|}{ Env B } & \multicolumn{2}{|c|}{$I-B$} & \multicolumn{2}{|c|}{ SR-B } & \multicolumn{2}{|c|}{$T R-B$} & \multicolumn{2}{|c|}{$\begin{array}{l}\text { Total } \\
\text { Score }\end{array}$} \\
\hline & $\mathrm{Pr}$ & Po & $\mathrm{Pr}$ & Po & $\mathrm{Pr}$ & Po & Pre & Po & Pre & Post \\
\hline MF & 15 & 17 & 52 & 58 & 28 & 28 & 6 & 10 & 101 & 113 \\
\hline ST & 12 & 16 & 51 & 64 & 26 & 30 & 10 & 10 & 99 & 120 \\
\hline RN & 11 & 10 & 34 & 44 & 17 & 23 & 6 & 7 & 68 & 84 \\
\hline VR & 7 & 11 & 34 & 51 & 19 & 27 & 5 & 10 & 65 & 99 \\
\hline AJ & 9 & 13 & 36 & 48 & 17 & 28 & 6 & 8 & 68 & 97 \\
\hline
\end{tabular}

Table 1 shows there is improvement in social skill as a whole on research subjects. It also shows the score of improvement for 
each aspects on each research subjects. The improvement of social skills can be seen from the change before and after group counseling. The illustration of score total can be seen on Graphic 1.

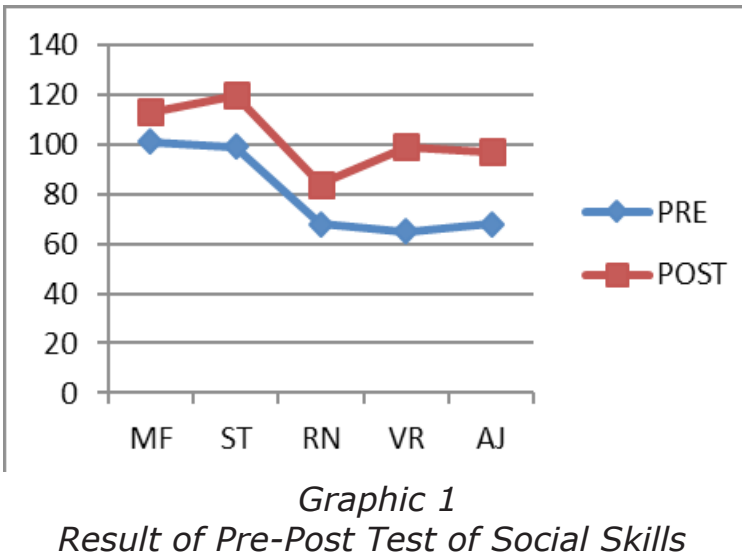

The blue line in graphic 1 shows the score of social skill before group counseling was delivered, meanwhile the red one is the score after the group counseling was delivered. The graphic describes that there is a score improvement before and after the treatment (group counseling).

The improvement occurred is significant. If it is seen from the difference of each score improvement (in \%), it can be assumed that the social skill improved because of group counseling delivery. In MF subject, the effectiveness of group counseling is $11 \%$ (score difference of pre-post/pre). While in subject ST, the effectiveness is $21 \%$; in $\mathrm{RN}$, it improved $23 \%$. Then, AJ gained $42 \%$ improvement of social skill. In addition, for subject VR, it has the highest improvement of $52 \%$.

From those five subjects, the highest of effectiveness level is subject VR due to some factors, such as the attendance during group counseling process, activeness, and giving suggestions during group counseling process.

The data analysis result of each subjects after having group counseling is described descriptively as the following, started from subject 1 until subject 5 .

After having conducted group counseling, score of subject MF increased, and the increase occurred on three social aspects of environmental, interpersonal, and self-related. It means the group counseling has become a treatment that improved MF social skills. If it is seen from score difference in pretest, the highest score was from interpersonal aspect. In self-related aspect score, MF does not change as MF still feels difficulty to think and behave positively and value himself/herself. This problem would be solved through individual counseling. From the total score, the significant improvement occurred from 101 points to 113 points. It means that the social score improved from middle category into high category.

After group counseling was given to ST, ST gained improvement on three aspects, namely environment, interpersonal, and selfrelated. In task-related aspect, ST did not gain score change. The aspect that gained significant improvement is interpersonal aspect. It occurred because ST learnt many ways about social interactions and relationships with people. The total score gained significant improvement from 99 points into 120 points, it means it improves from middle category into high category.

The score of RN before and after treatment was changed. After having group counseling, there was improvement in four aspects, namely environment, interpersonal, self-related, and task-related. Yet, from RN score, the improvement is not significant in aspects of environment and task-related. The total score of RN gained significant improvement with 16 points difference. From this score, it means it improved from low category into middle category.

VR score before and after treatment was change. After having conducted group counseling, there are four aspects that gained improvement, namely environment, interpersonal, self-related, and task-related. The significant score difference occurred in interpersonal behaviour aspect, which means that VR has learned many ways to interact with people, and some suggestions from other group members were well accepted. The total score difference is 34 points which means there is a significant improvement to VR social skill from low category into middle category.

The score of AJ before and after treatment gained change. After given group counseling, there are four aspects of social skill improved, namely environment, interpersonal, self-related and task-related. The aspects that changed significantly are interpersonal and self-related, which means AJ has learnt many ways of how to respect people and be responsible to himself/herself. The difference of total score is 29 points, which means there is a significant improvement to AJ's social skills from low category into middle category. 


\section{Analysis of Students' Social Skills Improvement}

Based on statistical data presented in graphic 1, all research subjects obtained social skill score improvement. Out of five subjects, three subjects obtained score improvement from low category into middle category, meanwhile, the rest two subjects gained improvement from middle category into high category. It shows that the improvement of students social skills as the result of group counseling delivery assumed to be effective in some sessions.

There are main problems occurred in five subjects. First, they got difficulty to communicate well with people which led to negative thoughts and different point of view to social environment. Second, they were confused of which appropriate responses should be given when communicating with people. Third, they got difficulties to express their emotion appropriately and felt pressured. Fourth, they felt stressed when interacting with people. Fifth, they could not handle interpersonal conflict. Lastly, they tended to avoid social environment. All those problems are obstruction to subjects' social skill in making social interaction and makes their emotion uncomfortable.

The theory of social skills is divided into two dimensions, namely cognitive and affective. In this study, the dimension focused to be changed was cognitive. This dimension functions to help individual to control emotion and behaviour in order to be in harmony with environment.

One of the aspects of social skill related to cognitive dimension is cognitive restructurization which rebuilding selfconfidence system from irrational to rational through understanding the negative thinking that often occurs, and facing helpless feeling by bringing out more self-positive understanding and being realistic to see him/ herself (Catrledge \& Milburn, 1993: 14).

Problems occurred from five research subjects during the process of group counseling were different from one another, but they could still be categorized into social interaction problems. One of the barriers was the occurrence of negative thoughts from these five subjects which made them difficult to express their emotion and behaviour to the environment.

The emotion barrier experienced can be caused by some factors, such as traumatic experiences of being ignored by parents or bullied by friends, strict parenting pattern, broken home family, etc.

Ellis (in Patterson, 1986) explains that individual showing inaccuracy to value something can possibly be caused by irrational thinking. It is shown that individual behaviour relating to emotional feelings of happy, sad, frustrated is not caused by what happened to him/her but more relates to what he/ she is thinking, or relating to individual belief system. The irrational belief triggered emotional reaction from individual which led to individual inappropriate behaviour and reaction.

In the steps of group counseling process, the counselor used cognitive approach of cognitive restructurization by trying to find out the negative thought of subject. Again, It is a restructurization or rebuilding selfconfidence system from irrational to rational through negative thinking understandings that often occurs, and face helpless feeling by bringing out more self-positive understanding and being more realistic to see him/herself.

The processes were conducted step by step. Firstly, the counselor tried to do counseling using cognitive approach in some sessions, mainly in productivity step. If the subject expressed negative thought, then the counselor would dig and identify things that made the subject afraid to think. After that, counselor ordered the subject to reflect back so that he/she could realize that their negative thoughts did not actually happen. The counselor asked the subject to show facts supporting the negative thoughts occurred, then the counselor asked the other group members to tell their own experiences or give positive and motivated suggestions.

By using group counseling, each group members has active role to give suggestion, to tell their own problems, to express emotion, to respect and motivate each other, and to give positive feedback which will create atmosphere of togetherness, being open to each other, trust each other, and sense of belonging (self belonging) of one another. All these situations will trigger therapeutic factors among members during the counseling (Yalom, 1985).

The therapeutic factor meant is relationship between counselor and group members in healing and solving problems involving psychology functions such as empathy, attachment, warmth, and intimacy. 
The therapeutic factors here refer to Yallom theory, i.e. the instillation of hope, imparting information, universalitas, altruisme, development of socializing technique, and interpersonal learning (Yalom; 1985).

In each steps of counseling process, the therapeutic factors occurred can be different depending on group dynamics. In this study, the first session of group counseling started with instilling hope to each subjects until they realized that the importance of group counseling was to help them to solve their problems. After that, the counselor imparting important information to group members. Some informations given in this step were about duties of adolescent development in social life and ways to be more socially skilled.

Each group members felt that group is their media in finding out insight. The suggestion given by each members became their considerations. They learnt more from other members' experiences and tried to reflect those experiences to themselves, which make them to have new perceptions and point of views about social environment and themselves. Subjects that have been found the insight and had more positive point of views such as ST, RN, VR \& AJ, will be able to improve fast and learn to find new acceptable behaviour in social environment.

The change or improvement was measured using questionnaire of social skill and resulted in form of quantitative data of pre and post-treatment. From statistical test, it can be drawn conclusion that group counseling is effective to improve the students' social skill in Telkom University.

\section{The Influence of Group Counseling to Students' Social Skill Aspects}

From the result of statistical test, the effectiveness of group counseling significantly affected the improvement of interpersonal skill aspect. The other aspects did not yet shown the effectiveness significantly. Based on statistical test using SPSS 15, the processed data of group counseling influence to interpersonal behaviour aspect was obtained on Tabel 2.

From data in the table 2, based on statistical test of Wilcoxon Signed Rank Test, $Z$ value is -2.023 . With the significance level $a=0,05$, P value obtained was 0.043 . From statistical test, it can be concluded that there is improvement before and after group counseling to interpersonal behaviour aspect. Hypothesis $\mathrm{H} 1$ was accepted, which means there is improvement before and after treatment.

\section{Table 2 \\ Statistical Test}

Test Statistics ${ }^{b}$

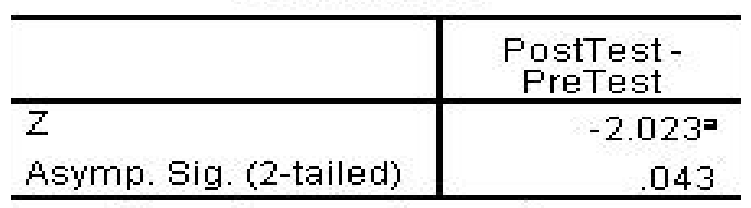

a. Based on negative ranks.

b. Wilcoxon Signed Ranks Test

From the description above, it can be said that group counseling delivery has significant influence to interpersonal behaviour aspect of students. Descriptively, it can be describe that interpersonal aspect is the main aspect that influence social skill improvement. The interpersonal aspect is a skill to interact with others, thus the interpersonal behaviour aspect should be more focused on in improving students' social skill. During the group counseling, most students obtained insight from their relationship with other group members in order to change themselves into a better person.

\section{Conclusion}

As the result of discussion, it can be concluded group counseling is effective to improve students's social skill in Telkom University. Out of five subjects given group counseling, three subjects ( $R N, V R \& A J$ ) obtained improvement from low category into middle category, meanwhile, the rest two subjects (MF, ST) obtained improvement from middle category into high category. It shows that the improvement of students' social skill as the result of group counseling delivery assumed effective delivered in some sessions. Qualitatively, the description of analysis is elaborated as follows: MF obtained a quite significant improvement where the subject was able not to reactively think in negative ways about other people if they showed unpleasant responses such as not smiling, silent, or talk less. To people whom he/she just met, the subject tried to learn how to start the conversation and to be relax in interacting with other people. The subject also learnt to express the thought and feelings 
which usually kept inside (assertive).

For subject RN, the improvement was felt until the end of counseling where the subject has started to be more confident in doing interaction, learnt to start the conversation, and learnt to have positive thinking about himself/ herself. In the end of group counseling, the awkward body language and fear has decreased.

Subject VR felt improvement in understanding social situation and people feelings, thus the subject tried to be a better person. The subject also tried to start simple conversation and smiled to friends. In addition, the subject learnt to respect others by saying thank you after being helped because previously the subject did not understand that saying thank you was a form of respecting other.

The changes that occurred to $\mathrm{AJ}$ were able to learn many about understanding social situations and knowing people. The subject also able to talk better and to be empathy because has learnt many from experiences told by other group members.

For ST subject, the improvement that occurred was able to understand people, to control intonation and face expression (smiling more than showing gloomy expression), not to think negatively about friends who stay away from him/her. learnt to be more open and start the conversation, and more patient in facing people whom she/he was talking with.

The delivery of group counseling has been effective to improve students' social skills in interpersonal behaviour aspect; meanwhile the three other aspects of environmental behavior, self related behavior, and task related behavior have not yet significantly effective based on statistical test conducted.

Some cases that need to considered for further study are group counseling for study programs in Telkom University. Group counseling can become a program that helps students to solve problems relating to their social environment adaptation. If a group counseling is held, it is better to focus on interpersonal behaviour aspect, so that the social interaction skill can be trained.

In this study, the time length to create action plan and control through individual counseling was limited, thus the researcher had difficulty to see changes or improvement of social skill. Furthermore, it is expected that further studies can give more time to train group members in creating action plan.

\section{References}

Agustina, L. (2017). "Konseling Kelompok Berbasis Teknik Self-Management Tazkiyatun Nafsi: Suatu Intervensi Psikologi Dalam Peningkatan Self-Direction In Learning Siswa." Jurnal Psikologi, Vol.13, No.1, pp $1-11$.

Corey, M.S., Corey, G. and Corey, C. (2008). "Groups, Process and Practice". Eight Edition. USA: Brooks/Cole.

Cartledge, G. Milburn, J. F. (1993). Teaching social skills to children and youth: Innovative approaches (3red). Boston: Allyn and Bacon.

Gimpel, G. A., \& Merrel, K. W. (1998) . "Social Skills of Children and Adolescents": Conceptualization, Assessment, Treatment. Mahwah, NJ : Erlbaum.

Kurnanto, M.E (2013). "Konseling Kelompok" Jakarta: Alfabeta.

Laursen. (2005). "Bimbingan dan Konseling (Studi dan Karir)." Yogyakarta: Andi Offset.

Latipun (2008). "Psikologi Konseling Edisi ketiga." Malang: UPT Penerbitan Universitas Muhammadiyah.

Patterson, C.H. (1986). "Theories of Counseling and Psychotherapy". New York: Harper \& Row, Publishers.

Prayitno, (1995). "Layanan Bimbingan dan Konseling Kelompok". Jakarta: Ghalia Indonesia.

Ramdhani, N., (1994). "Pelatihan Keterampilan Sosial pada Mahasiswa yang Sulit

Bergaul, Tesis S2". Yogyakarta: Program Studi Pasca Sarjana UGM.

Republik Indonesia. 1989. Undang-undang No. 2 Tahun 1989 tentang Sistem Pendidikan Nasional. Lembaran Negara RI Tahun 1989, No. 5. Sekretariat Negara. Jakarta.

Seniati, L., Yulianto, A., Setiadi, B. (2005). "Psikologi Eksperimen". Jakarta: PT Indeks

Yalom,I., (1985). "The Theory and Practice of group Group Psychoterapy". Third Edition. Newyork; Basic Books. 